\title{
Information Seeking Behaviour of Library Users of Mother Teresa Women's University, Kodaikanal - A Study
}

\author{
Kavitha $\mathrm{R}$ and Aravind $\mathrm{S}$ \\ ${ }^{1}$ Department of Library and Information Science, Mother Teresa \\ Women's University, Kodaikanal, Dindigul District, India \\ Librarian and Head, Central Library and Department of Library and Information Science, \\ G.T.N. Arts College (Autonomous), Dindigul, India \\ Corresponding author email: kavitharamalar@gmail.com
}

\section{ABSTRACT}

The present study aims to find out the information seeking behaviour of Library users of Mother Teresa Women's University, Kodaikanal. A samples of 125 library users selected randomly were studied. Primary data were collected by using a structured interview scheduled. All the library users were asked the some questions in the same fashion and they were informed the purpose of study. Percentage analysis, Cross tabulation and Chi-square test were applied to test the hypotheses. The findings and observations are the result and outcome of the interpretations made during the study of analysis.

\section{KEY WORDS: INFORMATION SEEKING BEHAVIOUR, USERS AND DEMOGRAPHIC VARIABLES.}

\section{INTRODUCTION}

Information seeking behaviour is defined as any activity of an individual that is undertaken to identify a message that satisfies a perceived need. Information seeking begins when someone perceives that the current state of possessed knowledge is less than needed to deal with some issue problem. The process ends when that perception no longer exists. People seek information in a variety of circumstances and from a variety of sources. The developments in information storage, retrieval and derived dissemination methods affect the information scientists. The individual seeking information need not be concerned with how the information is stored but should be concerned with how much information is stored and what kind of information is stored. One will be concerned about the case and comprehensive of retrieval

Biosc Biotech Res Comm P-ISSN: 0974-6455 E-ISSN: 2321-4007

\section{crossef}

Identifiers and Pagination

Year: 2021 Vol: 14 No (5) Special Issue

Pages: 202-205

This is an open access article under Creative

Commons License Attribn 4.0 Intl (CC-BY).

DOI: http://dx.doi.org/10.21786/bbrc/14.5/37 mechanists, but most of all one will be affected by the delivery mechanisms.

In relation to basic human needs the new technology is likely to have some effect on the information seeking habits of those concerned for empirical knowledge and for corporate human experience and entertainment. In the short term it is not likely to have a major effect on the seeker for personal human experience or on those seeking corporate human experience. In the longer term, more information may be stored in all types of format as the community recognizes the wide range of material encompassed by corporate human experience. Then there will be a considerable change in user habits. Information seeking behaviour is an area of active interest among many librarians, information scientists, communication scientists, sociologists and psychologists. Information seeking behaviour results from the recognition of some need, perceived by the user, whom as a consequence maker depends upon formal system such as libraries; information centers, on-line services, or some other persons in order to satisfy the perceived need.

It is influenced by a number of factors such as ones education together or not he/she has been taught how to use the products and services of information units,




ones working condition and amount of time available, ones hierarchical status and professional, position, how easily one gets on with people, how much competition there is between members of a group, the attitude of each individual/group, and previous experience etc.

Review of Literature: Bawden and Robinson (2016) conducted a study on the in formation needs and information seeking behaviour of nurses. The study mainly conducted by semi-structured interviews with them shows mid-wifery to be particularly information conscious, needing a wide variety of information and psychiatric nurses appear to be much less information conscious. Bijimol Joseph (2017) analysed the utilization of library facilities of the sree Chitra Tirumal Institute of Medical Sciences and Technology. The study deals with frequency of library visit by users, use of the library, availability of books and other resources, awareness of new materials acquired in the library, area of reading materials and adequacy of physical facilities.

Biradar and Sampath Kumar (2018) in their study attempt to evaluate the services and facilities offered by DVS Polytechnics College Library, Shimoga. The study shows that $37.5 \%$ students and $46.8 \%$ teachers are satisfied with lending service and $48.75 \%$ students and 50\% of teachers respectively have good opinion about bank facility of the college library. Aravind and
Kavitha (2020) Bibliotherapy has been widely recognized as an approach that helps librarians to betteraddress emotional, behavioral and social concerns. In the Indian context, bibliotherapy is still new, by conceptualizing ibliotherapy in a public library. The study will provide a better understanding of concepts bibliotherapy and make recommendations to the librarian by providing a description of and a rationale for the use of bibliotherapy by public libraries.139 responses received from public library readers of a chosen Central library and Selected Branch libraries in Dindigul Town.

The convenience sampling techniques were used. It is observed that more than half of the readers frequently read books like Poetry, Novels, Short stories and Motivational Books. 99 of the respondents (71.22\%) feel Difficulty in choosing the right self-help book. Two-third of the respondentsstrongly agree that reading self-help books 'Enable me to change my perspective towards life as I observe life from a different angle' (69.19\%), 'Inspire me to make better choices' (64.3\%). Further studies may be undertaken in other environments like schools, universities, working places, etc., to get a real picture of the effect of bibliotherapy.

\section{Objectives of the Study}

1. to find out the document wise user preference

2. to analyse the level of satisfaction about the

Table 1. Users Preference Of Types Of Document

\begin{tabular}{|l|c|c|c|c|c|c|c|}
\hline \multirow{2}{*}{ S.No } & Kinds of document & \multicolumn{7}{|c|}{ Order of Preference } & 4 & 5 & \\
\hline & & 1 & 2 & 3 & $40 t a l$ \\
\hline 1 & Books & $70(56.00)$ & $37(29.6)$ & $15(12.00)$ & $3(2.40)$ & - & 125 \\
\hline 2 & Periodicals & $30(24.00)$ & $60(48.00)$ & $29(23.20)$ & $4(3.20)$ & $2(1.60)$ & 125 \\
\hline 3 & Reference book & $19(15.20)$ & $19(15.20)$ & $43(34.40)$ & $39(31.20)$ & $5(4.00)$ & 125 \\
\hline 4 & Thesis and project works & $4(3.20)$ & $4(3.20)$ & $29(23.20)$ & $49(39.20)$ & $39(31.20)$ & 125 \\
\hline 5 & Conference proceedings & $2(1.60)$ & $5(4.00)$ & $9(7.20)$ & $30(24.00)$ & $79(63.20)$ & 125 \\
\hline & Total & 155 & 155 & 155 & 155 & 155 & 625 \\
\hline
\end{tabular}

Figures in parenthesis denote percentage value

$\begin{array}{lccc}\text { Calculated Chi-square value } & = & 496.1 & \\ \text { Degrees of freedom } & = & 16 \\ \text { Level of significance } & = & 1 \%\end{array}$

Ho:- Students differ in their preference of type of documents.

\section{METHODOLOGY}

The survey collected data to describe respondent's information seeking behaviour and to relate this behaviour to a number of variables. The survey form included questions about characteristic of the respondents that might influence their information seeking behaviour. A questionnaire was designed for the purpose of collecting the required data from the chosen sample user population. The questionnaire comprehensively includes broadly all the aspects regarding library, with on ultimate objective to reflect the user's opinion on the library. In this study in all 200 questionnaires were distributed among the students in the disciplines Arts and Science colleges in Nagai district. Out of 200 questionnaires distributed, 150 were-received back, making the response rate 75\%. Twenty-five questionnaires were not taken into consideration for they did not include complete answers. 
In all 125 users of Mother Teresa Women's University, Kodaikanal were analysed for the present study. Random sampling method adopted in this present study.

\section{ANALYSIS AND DISCUSSIONS}

The analysis of the responses furnished by the respondents in respect of their preference to various kinds of information resources indicate that among the 125 respondent of the study majority of the respondent preferred only books (56\%) followed by periodicals (24\%), and reference books (15.20\%). Thus, it can be concluded that books and periodicals occurred the highest (ICIII) - preference and the thesis, project work, conference proceedings are the lowest in the order of preference. It could be seen clearly from the above discussion most of the respondent used books for their examination purpose. This is statistically proved by the obtained chi-square test, which is significant. So the stated hypothesis is accepted.

Table 2. Satisfied Rate And Not Satisfied Rate With The Library Collection

\begin{tabular}{|c|c|c|c|c|c|c|c|}
\hline S.No & $\begin{array}{l}\text { Library } \\
\text { Collection }\end{array}$ & $\begin{array}{c}\text { Very } \\
\text { Satisfied }\end{array}$ & Satisfied & Unsatisfied & $\begin{array}{l}\text { Very Un } \\
\text { satisfied }\end{array}$ & No Opinion & Total \\
\hline 1 & Book collection & $38(30.40)$ & $48(38.40)$ & $18(14.40)$ & $8(6.40)$ & $13(10.40)$ & 125 \\
\hline 2 & Periodical & $36(28.80)$ & $49(39.20)$ & $20(16.00)$ & $12(9.60)$ & $8(6.40)$ & 125 \\
\hline 3 & Reference Books & $37(29.60)$ & $43(34.40)$ & $23(18.40)$ & $15(12.00)$ & $7(5.60)$ & 125 \\
\hline 4 & Stock coverage & $34(24.20)$ & $41(32.80)$ & $28(22.40)$ & $18(14.40)$ & $4(3.20)$ & 125 \\
\hline 5 & Bound journals & $31(24.80)$ & $38(30.40)$ & $26(20.80)$ & $12(9.60)$ & $18(14.40)$ & 125 \\
\hline 6 & News paper & $28(22.40)$ & $33(26.40)$ & $29(23.20)$ & $19(15.20)$ & $16(12.80)$ & 125 \\
\hline 7 & Stock currently & $27(21.60)$ & $34(27.20)$ & $30(24.00)$ & $23(18.40)$ & $11(8.80)$ & 125 \\
\hline 8 & $\begin{array}{c}\text { Archives and special } \\
\text { collection }\end{array}$ & $21(16.80)$ & $18(14.40)$ & $43(34.40)$ & $15(12.00)$ & $28(22.40)$ & 125 \\
\hline 9 & Video/tape/slides & $9(7.20)$ & $12(9.60)$ & $39(31.20)$ & $24(19.20)$ & $41(32.80)$ & 125 \\
\hline \multirow[t]{2}{*}{10} & Maps & $10(8.00)$ & $11(8.80)$ & 37 (29.60) & $29(23.20)$ & $38(30.40)$ & 125 \\
\hline & Total & 271 (21.68) & $327(26.16)$ & 293(23.44) & 175 (14.00) & $184(14.72)$ & $1250(100.00)$ \\
\hline
\end{tabular}

Figures in parenthesis denote percentage value

Calculated Chi-square value

$=$

217.8

Degrees of freedom

$=\quad 36$

Level of significance

$=$

$1 \%$

Ho:- Student differs in their level of satisfaction about the various facilities available in the library.

It is inferred from the table that nearly $68 \%$ of the students satisfied about book collection, 85\% satisfied about periodical, $80 \%$ satisfies regarding reference book, 75\% satisfied about stock coverage, 69\% satisfied about bound journals, $61 \%$ of them satisfied about stock currently, 39\% of them satisfied about archives and special collections, $21 \%$ of them satisfied about video/ tape/ slides and 21\% of them satisfied about maps. Therefore among the various sources, mast of them satisfied about periodical and reference books. This is also proved by the obtained Chi-square test, which is significant at 1\% level. So the stated hypothesis is accepted. Therefore, students differ in their level of satisfaction about various facilities available in the library.

\section{CONCLUSION AND IMPLICATIONS}

Library is the great source to the students and teachers to enrich their knowledge. So the University Grand Commission should sanction more funds to improve the infrastructure facilities. To increase the availability of International Journal and Foreign periodicals subscription. The library should procure new edition of current documents. Most of the students have demanded for video display on recent development. Inter library loan facilities should be improved. User suggestions enable a library to become aware of its problems and resolve these in a benefiting manner. If these suggestions are implemented, the user will have greater appreciation and respect for the role of library and its staff in supporting their academic requirements. This will ensure the full co-operation and support of the users. Who will then regard the library as their own.

\section{REFERENCES}

Ahanene, E.M. (2015). Use of library and Information services in development planningcase of local government decision makes in Imo state, Nigera. Annals of Library Science and Documentation, 36,74-78.

Aravind S and Kavitha R (2020), Role of Public library Reader emotional in molding and healing: A bibliotherapical case study. International Journal of Psychosocial Rehabilitation, 24(6), 
6567-6573.

Bawden, D. and Robinson, K. (2016), Information behaviour in nursing specialists: a case study of mid-wifery. Journal of Information Science, 23, 407-421.

Bijimol, Joseph. (2017), An assessment of the utilization of library facilities of the Sree Chitra Tirumal Institute of Medical Science and Technology and society, 13(1\&2),110-125.

Biradar, B.S. and Sampath Kumar, B.T. (2018), Evaluation of Information Services and facilities offered by DVS Polytechnic College Library: a case study. Library Herald, 38(2), 112-120.

Ellis David et al. (1993), A comparison of the information seeking patterns of Researchers in the Physical and Social Sciences. Journal of Documentation, 49, 356-369.

Estabrook, L. Bird, C. and Gilmore, F.L. (1990), Job satisfaction automation makes a difference.
Journal of Library Administration, 13 (1\&t2), 175197.

Garvey, W.D. and Griffinths. (1996), "Studies of social innovations in scientific communication in psychology". American Psychologists, 21(11) 1019-1039.

Ginzberg, M.J.(1997),“A study of the implementation process". TIMS studies in the Management Science, 13, 85-102

Suresh Janag and Maheswarappa, B.S. (1998), "Information Seeking Behaviour of Physical scientists". A case study with reference to the Gulberge University. Kelpro Bulletin, 2 (1)h: 3842.

Tripathi, Manorama. (2000). Information Requirements in physical Sciences and Social Sciences. Library Herald, 38(2), 91-103

Wiberley, Stephen, et al. 1998. Users persistence in scanning lists of references". College and Research Libraries: 149-151. 